which is normal among his countrymen. But it is also certain that his would have been a powerful mediating influence in happier days, had he lived to see them; and British and French scholarship may mourn him as a German, while gratefully cherishing the memory of his unique services as a scholar.

James Hope Moulton:

\section{PAUL LIEBAERT.}

Though not killed on the field of battle, the young Belgian Abbé, Paul Liebaert, may be called a victim of the war. War was declared when he was recovering from a severe illness. With characteristic self-forgetfulness he refused to rest and laboured unceasingly, first as chaplain and almoner in his native town of Courtrai, then, when the British wounded prisoners began to arrive, in relief of their necessities. Not until his activities were stopped by the Germans did he seek and obtain permission to return to his quiet life at the Vatican Library. The loss of his private fortune gave him much anxiety about the future; but when Italy joined the Allies he determined to stay at Rome and look after the soldiers' sons. The work overtaxed his strength. He went off to hospital at Pallanza, where he has died of typhoid fever.

The son of a wealthy business man of Courtrai, he studied Palaeography at the Vatican Library under Padre Ehrle, and was put on the list of Scrittori or Assistant Librarians, on the unpaid list ; so that his time was practically at his own disposal. He had the two chief requisites of the palaeographer-a good photographic camera and facilities for visiting the libraries of Europe; and with these advantages he laid such solid foundations for his life-work, that he bade fair to become a second Mabillon. Some two thousand photographs of Latin MSS., along with methodical notes of the scribes' practices, were promising material for future publications; but, apart from magazine-articles, all that he had accomplished before his death was the co-editorship of the "Specimina Palaeographica Vaticana.'
How far his papers admit of publication, I do not know. But it may not be out of place here to mention the chief results he had reached in his projected History of the Corbie Scriptorium, as I learned them in conversation with him last Easter. He had detected three types of minuscule favoured at different periods at Corbie. The earliest (e.g., Paris 4403A, foll. I84v sqq.; Paris I2239; Paris I3047) he called the emtype, from its peculiar form of the letter $e$ when in ligature with $m$ (or $n$ or $r$, etc.). The second is the type seen in that famous Bible in Amiens Library, which was written during the abbacy of Maurdramnus (772-780). This Maurdramnus type, as he called it, was succeeded in the abbacy of Adelhard by the ab-type. Three valuable clues for dating and locating MSS. of c. $75^{\circ}-$ c. 815 have thus been discovered by his diligence.

Primitice juvenis; but enough to show how much Latin Palaeography has lost by his premature death.

W. M. Lindsay.

\section{LEONARD CHEESMAN.}

THE Vice-Chancellor of Oxford in his October address chose out for mention three Oxford men as noteworthy among the many who have died in the war with all, or nearly all, their promise unachieved. One of these had seemed about to do good work in labour problems, one in politics; the third was G. L. Cheesman. And, indeed, the study of history has seldom lost so real an 'inheritor of unfulfilled renown.'

The tale of his life is short. He was a scholar of IVinchester and (1903-7) of New College. After taking his degree, he taught for a year at Christ Church, and then returned to New College as Fellow (June, Igo8). With the help of the College, he gave a year to travel in the provinces of the Roman Empire. In rgro he began regular teaching and lecturing, and began at the same time his own work on Roman history, and in particular on Roman military history. In IgI I he gained the Arnold Prize with an essay on the Roman auxilia; he wrote 